\title{
A rights-based analysis of disaster risk reduction framework in Zimbabwe and its implications for policy and practice
}

\author{
Authors: \\ Pathias P. Bongo ${ }^{1}$ \\ Paul Chipangura ${ }^{1}$ \\ Mkhokheli Sithole \\ Funa Moyo ${ }^{1}$ \\ Affiliations: \\ ${ }^{1}$ Institute of Development \\ Studies, National University \\ of Science and Technology \\ (IDS-NUST), Bulawayo, \\ Zimbabwe \\ Correspondence to: \\ Pathias Bongo \\ Email: \\ paradzayib@gmail.com \\ Postal address: \\ Institute of Development \\ Studies, National University \\ of Science and Technology, \\ 38 Duncan Road, Suburbs, \\ Bulawayo, Zimbabwe \\ Dates: \\ Received: 16 Aug. 2012 \\ Accepted: 11 Jan. 2013 \\ Published: 08 Apr. 2013 \\ Keywords: \\ disaster risk framework; \\ risk reduction strategies; \\ resilience; rights; \\ vulnerability \\ How to cite this article: \\ Bongo, P.P., Chipangura, \\ P., Sithole, M. \& Moyo, F., \\ 2013, 'A rights-based analysis \\ of disaster risk reduction \\ framework in Zimbabwe and \\ its implications for policy and \\ practice', Jàmbá: Journal of \\ Disaster Risk Studies 5(2), \\ Art. \#81, 11 pages. http:// \\ dx.doi.org/10.4102/jamba. \\ v5i2.81 \\ Note: \\ 1st Biennial Conference, \\ Southern African Society for \\ Disaster Reduction (SASDiR), \\ 09 to 11 October 2012, \\ Potchefstroom, South Africa.

\section{Read online:}

This paper examines closely the institutional arrangements for disaster risk reduction from a rights-based perspective. In Zimbabwe, the disaster risk reduction framework and the ensuing practice have not yet accommodated some of the most vulnerable and excluded groups, especially the terminally ill, people with disabilities and the very poor. Top-down approaches to disaster management have largely been blamed for lack of resilience and poor preparedness on the part of sections of society that are hard hit by disasters. Often, disaster risk reduction has also been modeled along the needs and priorities of able-bodied people, whilst largely excluding those with various forms of impairments. Against this background, this paper is based on field research on people's disaster risk experiences in four districts of Zimbabwe, with a special emphasis on the disaster risk reduction framework. It provides a critical analysis of the disaster risk reduction framework in Zimbabwe, focusing on the various forms of disadvantages to different categories of people that the current framework has tended to generate. The paper thus examines the current disaster risk reduction framework as largely informed by the Civil Protection Act and the Disaster Risk Management Policy Draft as revised in 2011. Crucial at this stage is the need to interrogate the disaster risk reduction framework, right from formulation processes with regard to participation and stakeholders, particularly the grassroots people who bear the greatest brunt of vulnerability, shocks, stresses and trends. In conclusion, the paper stresses the potential benefits of adopting an inclusive, rights-based thrust to disaster risk reduction in Zimbabwe.

\section{Introduction}

With the world faced with increasing frequency and intensity of disasters, the need for painstakingly concerted efforts toward building disaster resilient communities cannot be overemphasised. The increasing intensity and frequency of natural shocks and stresses due to climate change are disrupting livelihoods. The rain-fed agriculture-related base of most Southern African economies, including Zimbabwe, has made these countries particularly vulnerable to climatic extremes, disrupting people's seasoned livelihood modes. Exposure to disasters has also been said to increase the vulnerability of the poor, thereby deepening their poverty and preventing them from taking advantage of economic opportunities. Disasters can greatly reduce the gains made in development; and some development projects may inadvertently contribute to people's vulnerability when faced with a hazard event, situation or phenomenon. Based on studies in Bangladesh (Benson \& Clay 2002), Dominica (Benson \& Clay 2001) and Malawi and Zimbabwe (Benson \& Clay 1998), Benson and Clay (2004) show how disasters cause distortion in national budgets, moving away from capital expenditure toward relief and rehabilitation.

Prior to Zimbabwe's Independence in 1980, disaster management was referred to as civil defence. The concept had a militaristic connotation because it was designed during the War of Liberation (1965 to 1979) to serve the interests of a minority white population. At Independence (1980), this status quo was adopted and eventually civil defence was administered through the Civil Defence Act of 1982. The concept of disaster management has evolved and developed from civil defence to civil protection, and has now transformed into disaster risk management (DRM). This led to the enactment of the Civil Protection Act 5 of 1989 (Zimbabwe 1989). This shift has been necessitated by the domestication of international human rights and environmental agreements and the adoption of international best practices in disaster risk management in the form of the Draft National Disaster Risk Management Policy document (Zimbabwe 2011:6). This long road in the metamorphosis and reconfiguration of DRM issues in Zimbabwe has brought about positive changes in how disasters are addressed in the country. Nevertheless, there are some gaps that could still be covered as the consultative process for the drafting of a new disaster 
policy is happening in Zimbabwe. These gaps, in our view, hinge largely upon inclusiveness, exclusion and accessibility issues, especially with regard to people with disabilities (PWDs), the elderly, children, ethnic minorities and the very poor in society.

Informed largely by field-based evidence from four districts of Zimbabwe, namely Matobo, Shamva, Chirumanzu and Gwanda, this paper attempts to point out issues which could contribute toward mutual efforts in building up and maintaining a disaster-resilient nation.

\section{Rights-based approaches and Disaster Risk Management}

Albert and Hurst (2004:3) assert that human rights are a twentieth century phenomenon developed in response to the atrocities of World War II. They set out an internationallyaccepted moral code by which the intrinsic humanity of every individual is recognised and protected. Human rights are the fundamental, universal and indivisible principles by which every human being can claim justice and equality. A rights-based approach to development, at its core, is predicated on the principle that development should result in the empowerment of both socially- and economicallydisadvantaged groups (Ghai 2001). An underlying proposition is that a society that is committed to achieving social justice must implement social and economic rights. This seems commonplace on the face of it, but is proved controversial by the lack of political will in making this simple idea a reality (Ghai 2001:49). According to NyamuMusembi (2005:42), the rights-based approach suggests an integrated view of sustenance (economic and social rights) and freedom (civil and political rights) as complementary; each is necessary for the full realisation of the other. Kabeer (2002) writes of this linkage from the perspective of the purpose of rights, which is to ensure 'freedom of action'. Viewed from this perspective, both freedom from coercion (civil and political rights) and the freedom to access material resources serve the complementary purposes of protection and promotion of the ability to act. The Human Development Report 2000 had as its theme this linkage between human rights and human development, emphasising that although these two fields have followed separate disciplinary paths, they share the same goals: securing freedom for a life of dignity and expanding people's choices and opportunities (UNDP 2000). A rights-based approach adds an element of accountability and culpability; an ethical and/or moral dimension to development. It therefore demands a shift from viewing poverty eradication as a development goal to viewing it as a matter of social justice; as the realisation of a right and the fulfilment of a duty.

The right to development is a fundamental human right rooted in the provisions of the Charter of the United Nations (1945), the Universal Declaration of Human Rights (1948), the International Covenant on Civil and Political Rights (1966) and the International Covenant on Economic, Social and Cultural Rights (1966). The Declaration on the Right to Development (1986) made the right explicit, stating that the right to development is an inalienable right by virtue of which every human person and all peoples are entitled to participate in, contribute to, and enjoy economic, social, cultural and political development. In 1993, the World Conference on Human Rights affirmed the right to development by consensus. In general terms, a rights-based approach to development includes the following elements:

- express linkage to rights (in terms of protection, response, mitigation, etc. in relation to disasters)

- accountability (in the way that disaster risk initiatives are formulated and implemented)

- empowerment (of the people at risk of disasters, as they are the natural first responders in the event of a hazard)

- participation (as a way of strengthening community capacity and confidence to deal with future hazards and disasters)

- non-discrimination and attention to vulnerable groups (through use of inclusive and accessible methods and means in all aspects of disaster risk reduction (DRR), from awareness to actual practical implementation of DRR initiatives).

For a long time, DRM has been the sole preserve of international non-governmental organisations (NGOs), United Nations Agencies and professionals (Disaster Management specialists), without much involvement of the at-risk communities. When disaster events have affected people, there has been a tendency to put in place some mitigation and response mechanisms that have inadvertently excluded many classes of normally 'invisible' people like the very poor, PWDs, ethnic minorities, pregnant women, the elderly, illiterate and the sick, amongst others.

\section{History and overview of the Zimbabwean Disaster Risk Management Framework}

According to Chikoto and Sadiq (2012:7), following independence, the Government of Zimbabwe (GoZ) put in place supporting legislation to establish a sophisticated national emergency management system. As specified in the Civil Protection Act of 1989, during an emergency, this system would activate all available national resources, such as the setting up of a National Civil Protection Fund. If the resources of the GoZ are exhausted, a presidential declaration of national disaster would be made and regional and international resources would be sought. The first piece of legislation passed was the 1982 Civil Defence Act, wherein 'civil protection' was defined as 'any service provided or measure taken for the purpose of preparing for, guarding against and dealing with any actual or potential disaster' (Zimbabwe 1989:19). The 1982 Civil Defense Act was repealed by the Zimbabwe Civil Protection Act of 1989. Whilst the definition of 'civil protection' remained intact, the 2001 amended Act extends the definition of what 'disaster' means for the country. In recognition of the disasters that continue 
to or are likely to plague the country, the Civil Protection Act of 2001 (Chapter 10:06) defines 'disaster' as consisting of:

$$
\text { ... any }
$$

a) natural disaster, major accident or other event howsoever caused; or

b) destruction, pollution or scarcity of essential supplies; or

c) disruption of essential services; or

d) influx of refugees; or

e) plague or epidemic or disease; that threatens the life or wellbeing of the community (The Civil Protection Act 2001:Part I, s. 2). (Chikoto \& Sadiq 2012:8)

This legislation resulted in the creation of the Department of Civil Protection. The Department is currently housed within the Ministry of Local Government, Rural and Urban Development (formerly the Ministry of Local Government, Public Works, and National Housing), as the implementing body of the national government-initiated disaster preparedness and mitigation programmes (Chikoto 2004; United Nations International Strategy for Disaster Reduction [UNISDR] 2005). The Department of Civil Protection has always and continues to be responsible for coordinating all national response efforts (UNISDR 2005), and based on the Civil Protection Act 2001, its current primary functions include preparing for, preventing where possible, and mitigating the effects of, disasters once they occur.

Overall, the Department of Civil Protection's responsibilities encompass resource mobilisation in preparation for managing and responding to major emergencies and disasters. In addition to disseminating disaster managementrelated information, the department is also responsible for coordinating the training of civil protection officers, at all three levels of government - national, provincial, and district. Various levels, namely, the national, provincial, district, local authority and private and non-profit sector levels, are required to plan for disasters by producing operational plans for emergency preparedness and response - plans that would be activated in the event of a disaster (Zimbabwe 1989, 2001; UNISDR 2005). To assist in the planning process, the Department of Civil Protection appoints its own civil protection officers at both the provincial and district levels to mediate between these levels of government and the national government (InterWorks 1998). At the provincial level, the Provincial Administrators head and chair the Provincial Civil Protection Committees (PCPCs), whilst at the district level, the District Administrators head and chair the District Civil Protection Committees (DCPCs). Chikoto and Sadiq (2012:9) also go on to reveal that The National Civil Protection Committee, as required by law, is comprised of actors that would be involved in an emergency response in some capacity. Although chaired by the Director of Civil Protection, committee members are responsible for advising and assisting 'the Director in the planning and implementation of measures for the establishment, maintenance, and effective operation of civil protection' (The Civil Protection Act 2001, Part III, s. 4). The engagement of these actors is also strategic in nature in that it makes it easier to request their support in disaster and emergency situations. For instance, whenever activated, the emergency response might comprise the Zimbabwe Armed Forces, the Zimbabwean Air Force (helicopter support), the Zimbabwe Republic Police (ZRP) and its sub-aqua unit, and the local Fire Brigades, depending on the nature and scope of the disaster.

By 2003, plans had been set in motion to change the name of the Department of Civil Protection to the Department of Emergency Preparedness and Disaster Management under the newly proposed Emergency Preparedness and Disaster Management Act (Madamombe 2004). The GoZ in 2007 produced its first draft of the National Disaster Risk Management Policy. After some further consultations, the draft was revised in 2011 (Zimbabwe 2011). The 2011 edition of the Policy has been circulated to key stakeholders for their input, before finally being revised and adopted. To expedite the DRR policy framework in Zimbabwe, GoZ, through the Department of Civil Protection, hired a consultant in June 2012 to work on the finalisation of the policy framework. The nation awaits the outcomes of such a process in anticipation of a more resilient populace (see Figure 1).

\section{Research methodology}

This research used a mixture of both primary and secondary data to gain an impression of how people developed an understanding of the disaster risk management framework in Zimbabwe. The research was largely a survey. The fieldwork was limited to selected people from the Matobo, Chirumanzu, Shamva and Gwanda Districts, as well as Plumtree and Harare. People interviewed included Rural District Council (RDC) employees in the four rural Districts mentioned above, DRR specialists in Harare, community

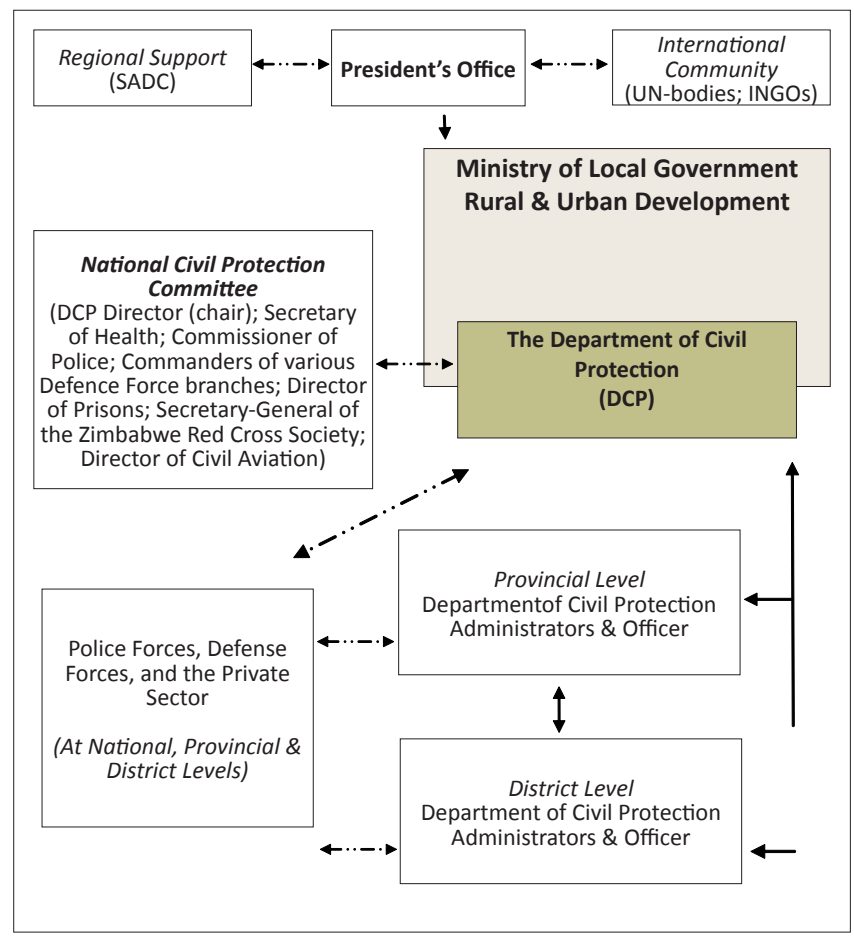

Source: Adapted from Chikoto and Sadiq (2012:9)

FIGURE 1: The structure of Zimbabwe's Disaster Management Policy Framework. 
members who were trained in DRR and Livelihoods by some NGOs, District level heads of Government Departments who participated in drafting District Disaster Management Plans for the three Districts, lecturers and researchers in Disasters from the Institute of Development Studies at the National University of Science and Technology (IDS-NUST), Diploma and Masters in Disaster Management students studying at IDS-NUST, and people not involved at all in disaster issues. In the survey, a total of 109 questionnaires was distributed to the categories of people indicated above.

\section{Sampling techniques}

The study used the non-probability purposive and convenience sampling methods, where the idea was to target specific people ranging from opinion leaders to the poorest of the poor in the rural areas. The aim was to target people who were directly involved in disaster and development issues at various levels, so as to elicit their views on disasters and their characterisation. A small portion of the sample was composed of people who did not have prior formal involvement in disaster issues. With these people, researchers sought to understand the mindsets of the 'common' person on disaster management policy. The understanding of the researchers was that disasters usually happen in a context dominated by these common people, in the sense of their not being formally involved in disaster issues. The survey did not make use of focus group discussions (FGDs). It was felt that data sources from secondary sources and impressions gained by the authors during general interaction with community members, disaster specialists and RDC employees in DRR work would be used to replace FGDs. In addition, the authors had already, in 2010, conducted some FGDs on disasters with community members in Bulilima, Gwanda and Mangwe Districts. Records of these FGDs constituted part of the secondary data sources utilised. The FGDs were conducted when the authors were training ward and district level DRM committees.

\section{Research methodology matrix}

Please see as indicated in Table 1.

\section{Disaster Risk Management Framework based on field research}

This section focuses on presentation of data collected from the field, zeroing in on the DRM framework in Zimbabwe.

The majority of respondents in the research pool (48.6\%) were in the 18- to 30-year age group. The second highest percentage was in the 31- to 40 -year age group, with $20 \%$. These two groups generally constitute most of the ablebodied people in society. This makes the selection relevant, as disaster issues usually have to do with physical effort in practical DRR initiatives in terms of training, mitigation and response, including search and rescue. The elderly (61 years and above) were also included in the research, to tap into their invauable knowledge built over years of experience with livelihoods and disasters (see Figure 2).

\section{Frequency of responses}

Table 2 shows the frequency of responses, based on a total of 109 questionnaires distributed to selected people in Matobo, Gwanda, Chirumanzu and Shamva Districts. Other questionnaires were administered in urban Harare and Plumtree. Matobo District had the highest percentage (25.7\%), followed by Gwanda (24.8\%), Chirumanzu (20.2\%), Harare city $(14.7 \%)$, Shamva $(9.2 \%)$ and finally, Plumtree town $(5.5 \%)$.

TABLE 1: Research methodology matrix.

\begin{tabular}{|c|c|c|}
\hline \multirow[t]{2}{*}{ Data collection/Tool and or Method } & \multicolumn{2}{|c|}{ Methodology } \\
\hline & Justification & Data source \\
\hline $\begin{array}{l}\text { - Questionnaires - mixture of closed and } \\
\text { open-ended questions } \\
\text { - } 20 \text { closed questions and } 6 \text { open }\end{array}$ & $\begin{array}{l}\text { - To elicit responses from subjects to derive different } \\
\text { conceptualisations of disaster risk management } \\
\text { framework } \\
\text { - Open-ended questions provide for flexibility in } \\
\text { responses, thereby accommodating diversity }\end{array}$ & $\begin{array}{l}\text { - Disaster Management students at NUST (mainly MSc } \\
\text { Disaster Management and Diploma in Disaster and } \\
\text { Development Management). } \\
\text { - DRR practitioners in NGOs } \\
\text { - Officers of relevant central and local Government } \\
\text { Departments }\end{array}$ \\
\hline $\begin{array}{l}\text { - Interviews - structured (key informant) } \\
\text { applied to the } 6 \text { open ended questions in } \\
\text { the questionnaire }\end{array}$ & $\begin{array}{l}\text { - To allow for subjective and interpretive responses } \\
\text { - For cross-checking responses given from } \\
\text { questionnaires and data collected through observation }\end{array}$ & $\begin{array}{l}\text { - Community members disaggregated according to gender, } \\
\text { age group, vulnerability status (e.g. disabled) } \\
\text { - DRR lecturers from NUST } \\
\text { - DRR trainees from NGOs }\end{array}$ \\
\hline - Field visits/ observation/ transect walks & $\begin{array}{l}\text { - Capturing phenomena that cannot be captured by } \\
\text { other methods, e.g. mood, and other non-verbal cues } \\
\text { - Production of transect profile of study areas }\end{array}$ & $\begin{array}{l}\text { - Shamva District } \\
\text { - Gwanda District } \\
\text { - Matobo District } \\
\text { - Chirumanzu District }\end{array}$ \\
\hline - DRR experts' opinion & $\begin{array}{l}\text { - Proper usage of DRR jargon } \\
\text { - Taking into account new DRR models and changes to } \\
\text { conventional/ common models and tools }\end{array}$ & $\begin{array}{l}\text { - DRR practitioners } \\
\text { - NUST lecturers }\end{array}$ \\
\hline $\begin{array}{l}\text { - Secondary data review (Disaster } \\
\text { Management Policy drafts [2007 \& 2011], } \\
\text { curriculum, project progress reports) }\end{array}$ & $\begin{array}{l}\text { - Capturing historical trend of phenomena under } \\
\text { investigation (DRR education and training) } \\
\text { - Comparing changes in various aspects of training and } \\
\text { resultant changes }\end{array}$ & $\begin{array}{l}\text { - DRR training modules/ manuals/ books } \\
\text { - DRR and development journals from the internet }\end{array}$ \\
\hline $\begin{array}{l}\text { - Content analysis (videos and posters on } \\
\text { DRR policy, training/ education) }\end{array}$ & $\begin{array}{l}\text { - Reliving and transcribing data that could not be } \\
\text { captured at the time of occurrence of events under } \\
\text { investigation (training and education) }\end{array}$ & $\begin{array}{l}\text { - Department for International Development-Conflict and } \\
\text { Humanitarian Fund (DFID-CHF) DRR videos 'Global Voices, } \\
\text { - Local Choices' } \\
\text { Field training videos (Practical Action, DFID and European } \\
\text { Union) }\end{array}$ \\
\hline
\end{tabular}

Source: Developed by authors for study 
TABLE 2: Frequency of responses.

\begin{tabular}{lcc}
\hline District/Town & Frequency & Percentage \\
\hline Matobo & 28 & 25.7 \\
Gwanda & 27 & 24.8 \\
Chirumanzu & 22 & 20.2 \\
Shamva & 10 & 9.2 \\
Harare & 16 & 14.7 \\
Plumtree & 6 & 5.5 \\
\hline Total & 109 & 100.0 \\
\hline
\end{tabular}

Source: Primary data collected for study

\section{Disaster Risk Management Framework issues}

\section{Educational qualifications}

Fourty-four percent of the sampled people indicated that their highest educational level was tertiary. 37\% indicated that they had gone up to secondary school level, $13 \%$ had been up to primary school level, whilst $6 \%$ had never been to school. The selection of a bigger number of literate people was deliberate, as the central issue for investigation was awareness of disaster policy, as opposed to disaster practices or initiatives, which any ordinary person can easily identify (see Figure 3).

\section{Understanding of disaster issues}

In general, respondents understood disasters to be events that negatively impacted on people's lives and livelihoods. What came out clearly was that the understanding of disasters was largely shaped by the most common and strongly-felt hazards and disasters in the respective Districts. In Matobo, disaster characterisation was largely related to road traffic accidents, in Gwanda to HIV and drought, whilst in Shamva and Chirumanzu, it was associated with general mishaps and hunger respectively.

\section{How disaster knowledge was gained}

Respondents were asked to indicate how they gained knowledge about disasters. In response to this, $34 \%$ said that they got to know through formal education, $28 \%$ through informal education, 15\% through television, 13\% through experience, $8 \%$ through radio, and $1 \%$ through internet. The dominant role of education in this (both formal and informal) was noted (see Figure 4).

\section{Major kinds of disasters experienced in the research areas}

Drought was the most common disaster experienced by respondents (62.2\%). 13.3\% of respondents felt that fire was the major disaster they experienced in their area, whilst $8.9 \%$ indicated traffic accidents, $4.4 \%$ human diseases (especially HIV), another $4.4 \%$ animal diseases, and the third $4.4 \%$ indicating other forms of disaster. The dominance of drought was also noted, with policy implications (see Figure 5).

\section{Knowledge of impending disasters}

Respondents were asked how they got to know about impending disasters. Eighteen percent indicated that they got to know through informal education, 13.8\% through television, $12.8 \%$ through radio, $11 \%$ through experience, whilst $0.9 \%$ pointed to internet and another $0.9 \%$ to

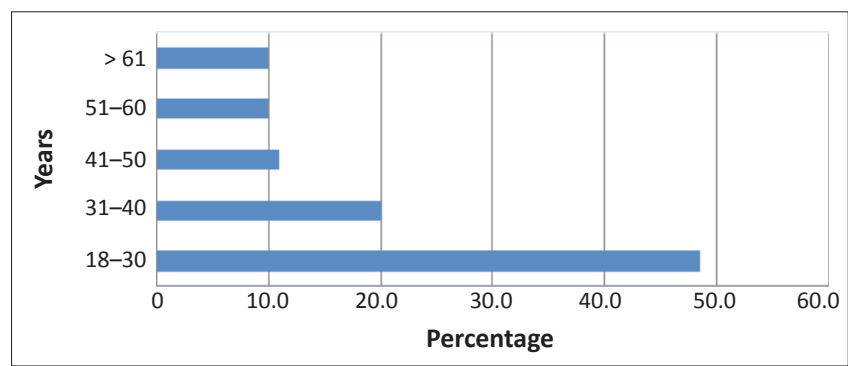

Source: Primary data collected for study

FIGURE 2: Age groups of respondents.

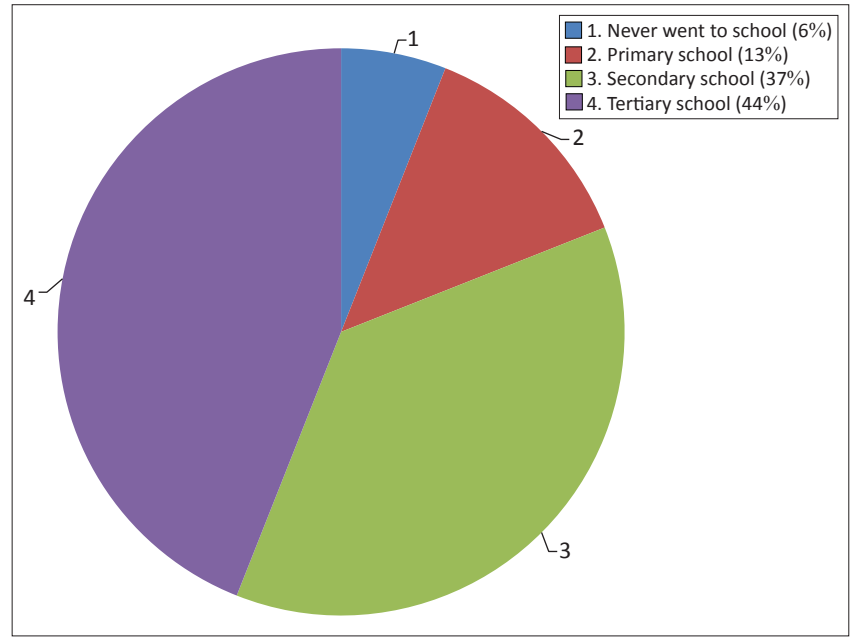

Source: Primary data collected for study

FIGURE 3: Educational qualifications of respondents.

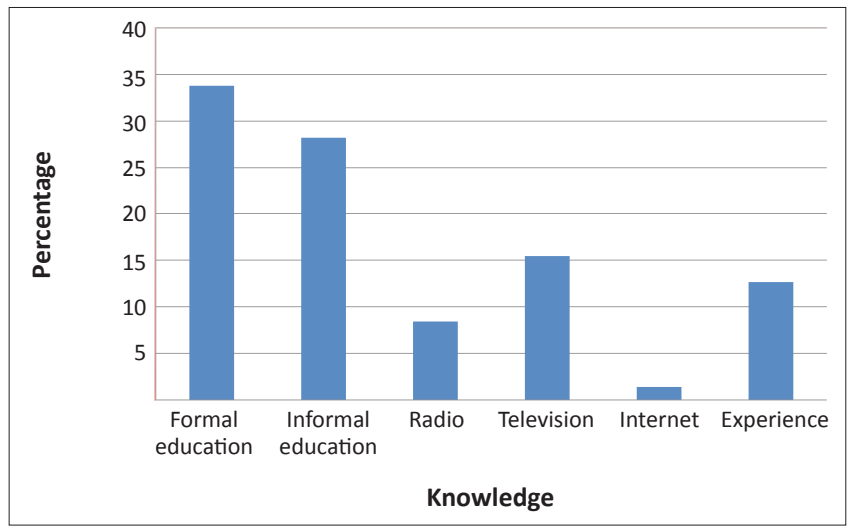

Source: Primary data collected for study

FIGURE 4: How disaster knowledge was gained.

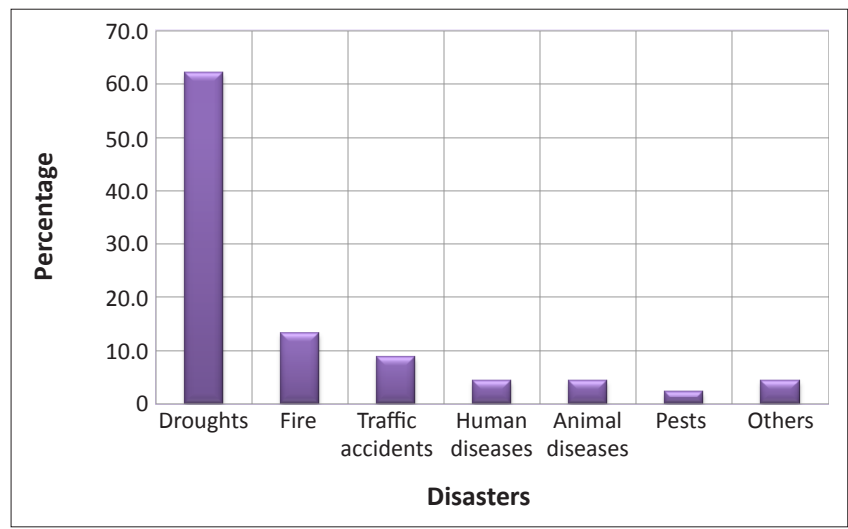

Source: Primary data collected for study

FIGURE 5: Major kinds of disasters experienced. 


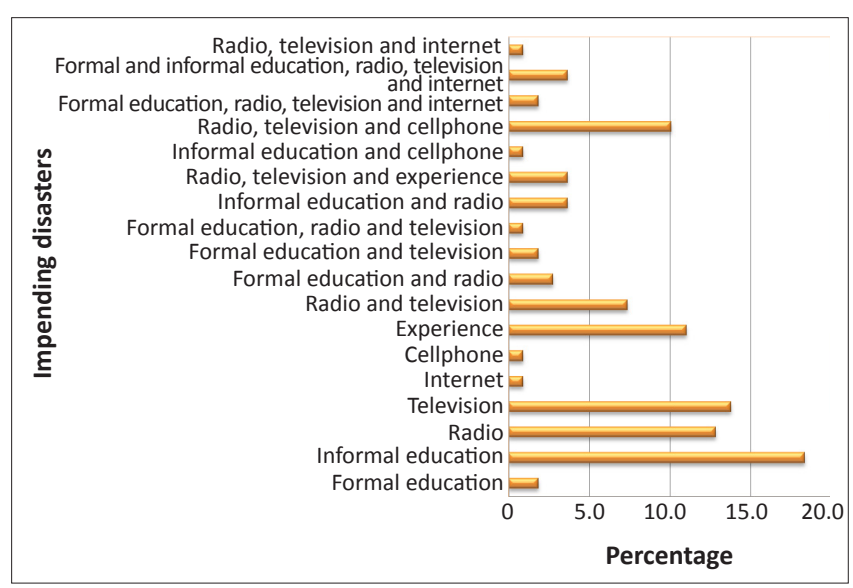

Source: Primary data collected for study

FIGURE 6: How knowledge on impending disasters is gained.

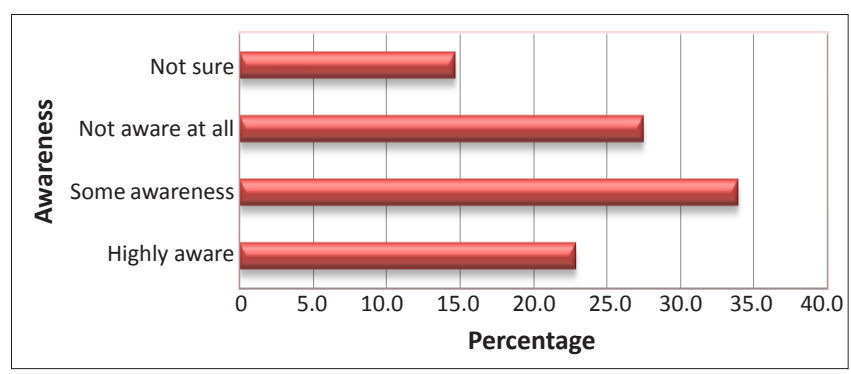

Source: Primary data collected for study

FIGURE 7: Awareness of Zimbabwean Disaster Management Policy.

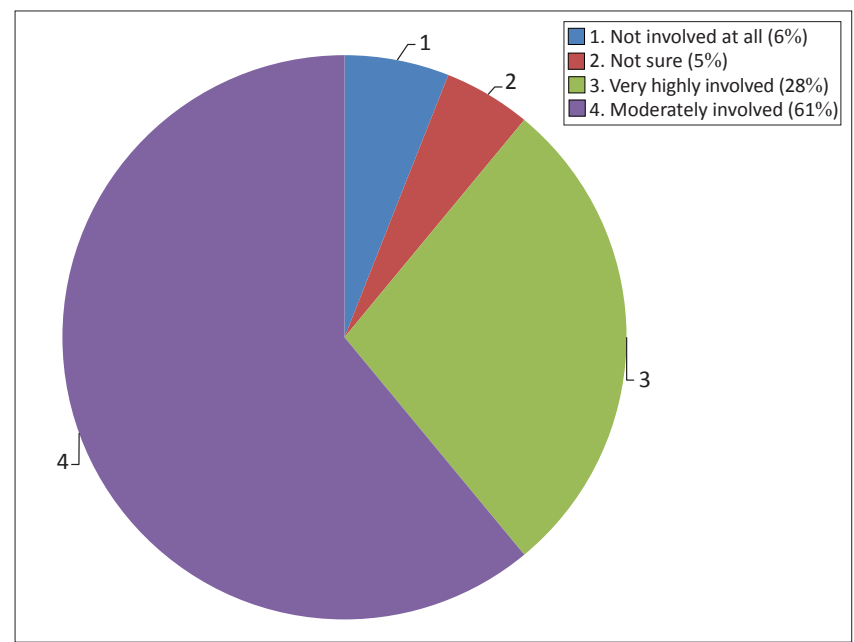

Source: Primary data collected for study

FIGURE 8: Extent of involvement in disaster situations.

TABLE 3: Disaster response experiences.

\begin{tabular}{lcc}
\hline Experiences & Frequency & Percentage \\
\hline People notify the police & 13 & 11.9 \\
The local leadership direct responses & 32 & 29.4 \\
$\begin{array}{l}\text { Members of the uniformed forces } \\
\text { move in to help }\end{array}$ & 9 & 8.3 \\
NGOs and UN move in assist & 23 & 21.1 \\
No one knows what to do & 5 & 4.6 \\
Other & 2 & 1.8 \\
\hline
\end{tabular}

Source: Primary data collected for study

NGOs, non-governmental organisations; UN, United Nations. cellphones. When considering combinations of information sources on impending disasters, radio, television and cellphone had the highest percentage, with a total of $10.1 \%$. There are other notable combinations of radio, television, experience and informal education that follow at 3.7\% (see Figure 6).

\section{Awareness of Zimbabwean Disaster Management Policy}

As a way of probing on policy, respondents were asked to indicate their awareness of disaster management policy in Zimbabwe. In response to this, 34.3\% indicated having some awareness, $27.8 \%$ indicated not being aware at all, 23.1\% were highly aware, and $14.8 \%$ were not sure (see Figure 7 ).

\section{Disaster response experiences}

The first point of inquiry under disaster response experiences was to find out what happened, in disaster response terms, when a disaster hit respondents' areas. Twenty-nine point four percent of respondents indicated that local leadership directed responses, $21.1 \%$ said that NGOs and the UN moved in to assist, $11.9 \%$ indicated that they notified the police, $8.3 \%$ said armed forces moved in to assist, whilst $4.6 \%$ indicated that no one knew what to do. In examining combinations of responses, $10.1 \%$ indicated that local leadership directed responses, and NGOs and the UN moved in to assist (see Table 3).

\section{Involvement in disaster}

Having responded to the issue of what happened in response terms in the event of a disaster, respondents were next asked to relate the extent to which they were involved when disasters hit their area. In response to this, $61 \%$ said they were moderately involved, $28 \%$ were very highly involved, $6 \%$ were not involved at all, and 5\% were not sure (see Figure 8 ).

The respondents were probed further to explain their mode of involvement in disaster situations in their area. In other words, the next enquiry was for them to identify reasons for why they were highly involved, moderately involved, not involved at all and not sure. In response to this, 31.1\% indicated that they were not very aware and sure of what to do, 30.2\% indicated they were aware and sure of what to do, $14.2 \%$ indicated there were barriers to their involvement, $11.3 \%$ felt they had no responsibility with regard to handling disasters, and $8.5 \%$ indicated that they were not aware at all about what to do (see Figure 9).

Next, the respondents were asked to indicate who should be involved in disaster issues in their areas. Their responses were as follows: $37.6 \%$ felt that government should be involved, $17.4 \%$ local government, $6.4 \%$ the uniformed forces, $5.5 \%$ other, $3.7 \%$ the health sector and $1.8 \%$ NGOs and UN agencies. This was done in an attempt to gauge their understanding of Zimbabwean disaster management policy (see Figure 10).

\section{Disaster policy and livelihoods \\ Disaster vulnerability ranking}

In disaster vulnerability ranking, the idea was to find out how respondents understood the various disaster risk 
vulnerabilities amongst different people in the community and the drivers of these vulnerabilities. They were therefore given the following people to rank, in order of degree of vulnerability, with the most vulnerable topping the list: person with a disability, old woman, widow, illiterate person, school-going child and an old man. In their responses, they came up with the following ranking:

1. person with a disability

2. old woman

3. school-going child

4. old man

5. widow

6. illiterate person.

\section{Sources of support in disaster}

Respondents were asked to indicate where they got support in times of disaster. Figure 11 below captures their responses. Twenty-five percent indicated getting support from NGOs, $14.7 \%$ from extended family, $13.8 \%$ from community, $12.8 \%$ from government, and $4.6 \%$ indicated that they received no support.

\section{Hazards and their impact on livelihoods}

Having been asked to show where they got support in times of disaster-induced hardships, respondents were next asked to rank a given list of hazards in terms of their impact on their livelihoods. The list of hazards was as follows: drought, flood, HIV, veld fires, crop pests and animal diseases, traffic accidents and other human diseases. An analysis of the means of responses produced the following rank, with the topmost hazard having the most impact on livelihoods:

1. drought

2. HIV

3. crop pests and animal diseases

4. traffic accidents

5. veld fires

6. other human diseases

7. floods.

When asked to explain their ranking above, respondents came up with the following responses, as encapsulated in Figure 12. The most outstanding reason given was the extent of damage that each hazard generated $(37.6 \%)$, followed by experience and familiarity with the challenge (hazard) $(18.3 \%)$, resources available to withstand the challenge $(13.8 \%)$, commonality of challenge $(11.9 \%)$, policy factors $(1.8 \%)$ and others $(1.8 \%)$.

\section{Self- and livelihood protection in disaster situations}

Respondents were asked to tell what they personally did to protect themselves and their livelihoods in disaster situations. $24.8 \%$ indicated that they engaged in crop-related activities, $14.7 \%$ in practical DRR activities, $12.8 \%$ in livestock-related activities, $12.8 \%$ in other unspecified activities, whilst $9.2 \%$ had undergone DRR training. In considering combinations, $10.1 \%$ indicated a combination of crop- and livestock-related activities.

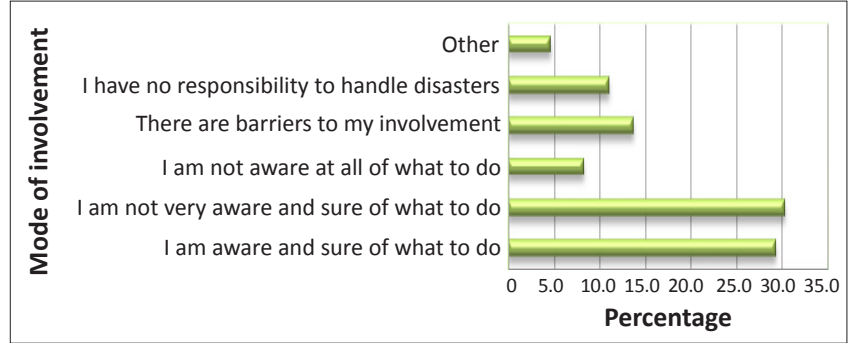

Source: Primary data collected for study

FIGURE 9: Reasons for mode of involvement in disasters.

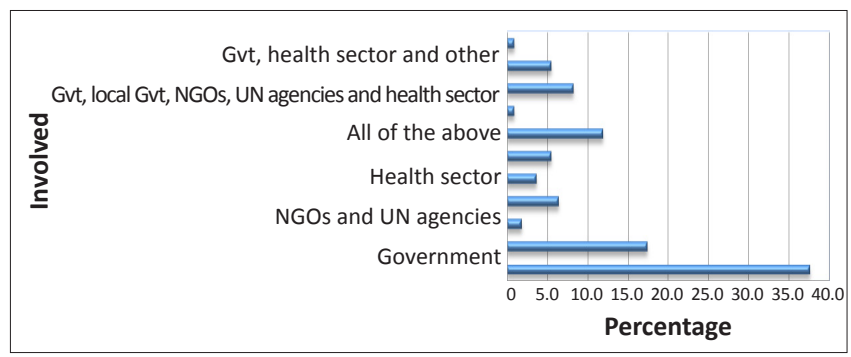

Source: Primary data collected for study

Source: Primary data collected for study

FIGURE 10: Who should be involved in disaster issues?

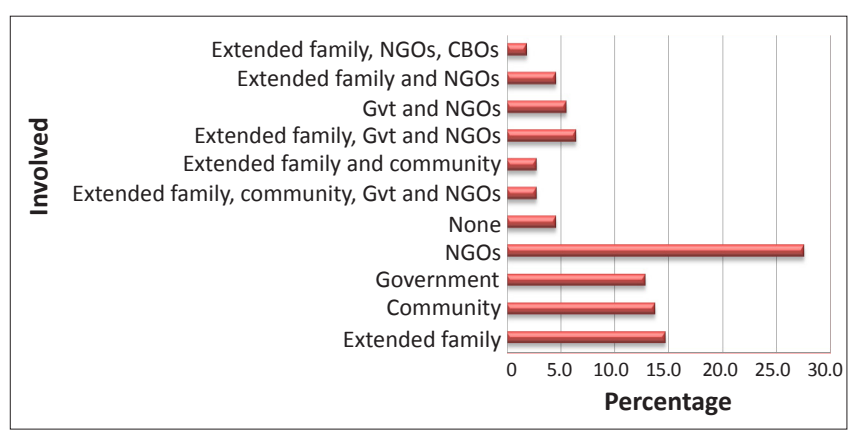

Source: Primary data collected for study

NGOs, non-governmental organisations; CBO, Community Based Organisations; GVT, government.

FIGURE 11: Support in times of disaster-induced hardships.

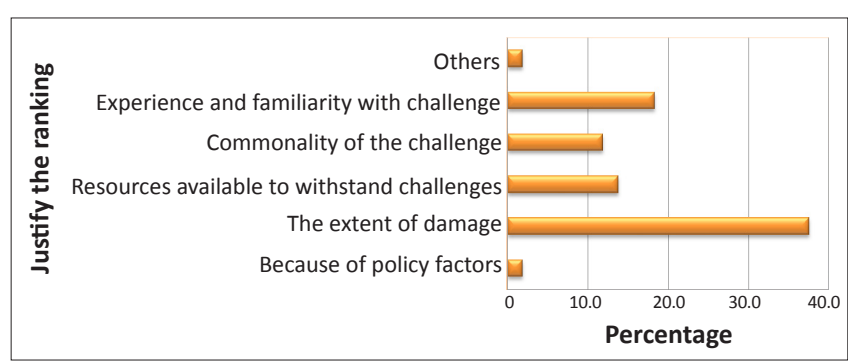

Source: Primary data collected for study

FIGURE 12: Reasons for hazard ranking.

\section{Inclusiveness of disaster risk reduction practices}

When asked to comment on the inclusiveness of DRR practices in Zimbabwe, respondents came up with myriad responses. The general feeling by most respondents $(80 \%)$ was that DRR policy and practice in Zimbabwe was not very inclusive some five years ago. Instead, it was the sole preserve of NGOs, UN agencies and some few professionals and experts in development and disaster management. Others also felt that less internet and communication coverage contributed to this 
lack of inclusiveness, particularly in regard to accessing DRR information, including early warning. Respondents indicated that presently, there is a movement toward DRR awareness, but not necessarily doing away with exclusion. Respondents felt that five years from now, most disaster impacts could be contained because of the progressively-increasing level of awareness raising happening countrywide. They emphasised the need for more coordination and partnership approaches to DRR, as these had the potential to make communities more disaster-resilient.

\section{Ability to respond to disasters}

The next point of inquiry was to find out how respondents rated their ability to respond to disasters. The following responses were recorded (Figure 13). It is important to note that $41 \%$ of respondents felt that their ability to respond to disasters was good and/or excellent. A total of $20 \%$ felt that their ability ranged from bad to worse.

\section{Improving the ability to deal with disasters}

Respondents were asked to air their views on how Zimbabwean society could improve its ability to anticipate, cope with, and respond to disasters. The following were the most common responses recorded:

- Train communities and conduct awareness campaigns on disaster management and environmental issues.

- Mobilise resources.

- Have effective early warning systems in place (use cellphones to communicate disaster risk, especially in rural areas).

- Participation - involve people in mitigation (allow people to share how they can be participating). Involvement of everyone in policy formulation, implementation and evaluation.

- Improve level of communication by disaster risk coordinating institutions.

- Cascade DRR to ward and village level.

- Political will and commitment at senior level, especially central government.

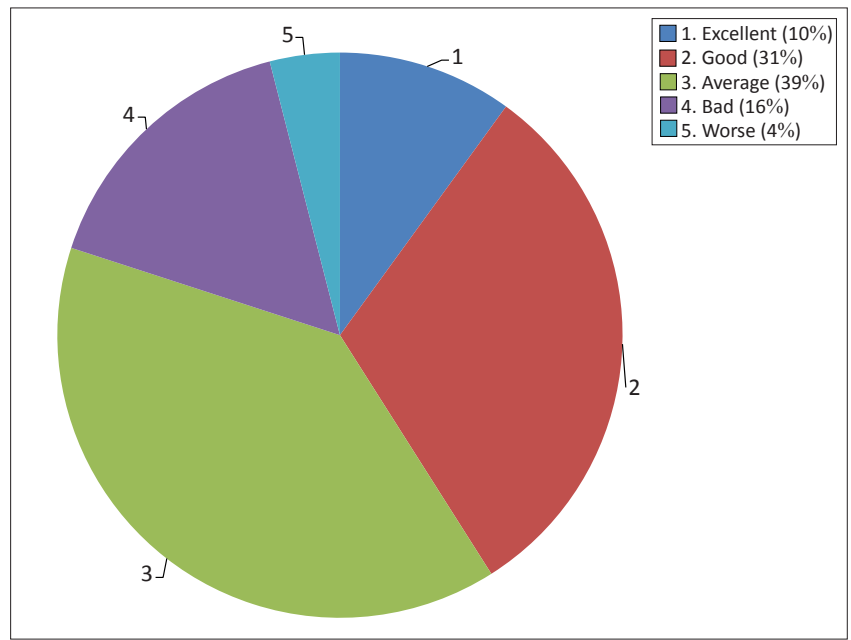

Source: Primary data collected for study

FIGURE 13: Self-rating on ability to respond to disasters.
- Community Based Organisations (CBOs) must be seen to be operational on the ground.

- Incorporate disaster education at all levels.

- Promote livelihood projects to boost community resilience.

- Translate disaster management materials into vernacular languages.

- Improve government and NGO relationship.

- HIV awareness.

- Sound farming practices and provision of seed, growing drought-tolerant crops (also irrigation support).

- Government to enforce laws, for example, control of speeding on the roads.

\section{Institutional involvement in disaster risk reduction}

Participants were next asked to list the institutions involved in disaster risk issues in their areas and to briefly indicate what these institutions did. After that, they were then required to rank the effectiveness of activities of these institutions on a scale with 1 being excellent and 5 being worst. The top 10 most common institutions (out of 53) recorded in the four districts were captured as follows, in order of their frequency (see Table 4).

\section{Discussion of research findings on disaster risk governance, policy and livelihoods}

Having presented the key research findings from the field, this section focuses on critical analysis of these findings in light of disaster risk governance, policy and livelihoods. From the data obtained it is evident that drought has been ranked the topmost disaster affecting the majority of people interviewed. This is also reflective of the situation at a national level in the country. Yet even though people can identify the key disaster or hazards that affect them, the majority is not even aware of the existence of a national drought mitigation policy. The policy was mentioned in passing by only a handful of respondents (about 3\%), and these were amongst the most educated people in the sample. This is not a positive picture, considering the fact that $44 \%$ of the sample went up to tertiary education, with another $37 \%$ having gone up to secondary school. If such comparatively educated people are not aware of the existence of a drought mitigation policy, let alone its operation, then there is a serious knowledge gap that needs to be addressed. It was noted that there is some degree of awareness of disaster policy in Zimbabwe on the part of respondents (a total of $57.4 \%$ indicated some and/or high awareness). However, when probed further to articulate the policy issues in greater detail, they could not provide convincing responses. Another indicator of this lack of awareness was the constant reference to the Department of Civil Protection (DCP) as the Civil Protection Unit (CPU). Over the years, the DCP has been referred to, erroneously, as the CPU, an institutional name that is not official for the entity. People were also not aware of the individual obligations and duties in times of disaster, as enshrined in the current legal instruments indicated earlier on. 
TABLE 4: Institutions and their involvement in disaster risk reduction.

\begin{tabular}{|c|c|c|}
\hline Name of Institution & $\begin{array}{l}\text { Main interventions and/or } \\
\text { activities }\end{array}$ & $\begin{array}{l}\text { Average Effectiveness } \\
\text { Ranking }\end{array}$ \\
\hline UNICEF & $\begin{array}{l}\text { - Sponsors vaccination and } \\
\text { immunisation programs } \\
\text { - Book distribution }\end{array}$ & 2.5 \\
\hline $\begin{array}{l}\text { Organization of Rural } \\
\text { Associations for } \\
\text { Progress (ORAP) }\end{array}$ & $\begin{array}{l}\text { - Provides food in times of } \\
\text { drought }\end{array}$ & 2 \\
\hline $\begin{array}{l}\text { Agricultural Research } \\
\text { and Extension Services } \\
\text { (Agritex) }\end{array}$ & $\begin{array}{l}\text { - Offers treated seeds for } \\
\text { better produce } \\
\text { - Technical advice on } \\
\text { cropping }\end{array}$ & 3.7 \\
\hline NGOs (in general) & $\begin{array}{l}\text { - Flood mitigation as well } \\
\text { as raising alarm on issues } \\
\text { of food } \\
\text { - Food relief, self-help } \\
\text { projects } \\
\text { - Food aid, trainings, } \\
\text { medication }\end{array}$ & 1.8 \\
\hline $\begin{array}{l}\text { World Health } \\
\text { Organization (WHO) }\end{array}$ & - Provides medical facilities & 2.3 \\
\hline $\begin{array}{l}\text { Zimbabwe AIDS } \\
\text { Network (ZAN) }\end{array}$ & - ARV supply & 4.3 \\
\hline $\begin{array}{l}\text { Ministry of Health } \\
\text { and Child Welfare } \\
\text { (Hospitals) }\end{array}$ & $\begin{array}{l}\text { - Response, training and } \\
\text { expert advice } \\
\text { - Health services } \\
\text { - Disease control } \\
\text { - Provision of medicines } \\
\text { - Workshops on disease } \\
\text { outbreaks }\end{array}$ & 2.3 \\
\hline $\begin{array}{l}\text { Zimbabwe Republic } \\
\text { Police (ZRP) }\end{array}$ & $\begin{array}{l}\text { - Security and manpower } \\
\text { - Attend to accidents } \\
\text { - Task force leading } \\
\text { emergency response } \\
\text { - Search and rescue }\end{array}$ & 3.1 \\
\hline $\begin{array}{l}\text { Rural District Councils } \\
\text { (RDCs) }\end{array}$ & $\begin{array}{l}\text { - Response and training } \\
\text { - Coordination } \\
\text { - Mobilise resources } \\
\text { - Social protection } \\
\text { - Farming education }\end{array}$ & 2.5 \\
\hline $\begin{array}{l}\text { Environmental } \\
\text { Management Agency } \\
\text { (EMA) }\end{array}$ & $\begin{array}{l}\text { - Training and expert advice } \\
\text { - Enforces the law } \\
\text { - Fire management } \\
\text { - Prevention and control } \\
\text { of environmental } \\
\text { degradation }\end{array}$ & 3.3 \\
\hline
\end{tabular}

Source: Primary data collected for study

ARV, Antiretroviral drug; NGOs, non-governmental organisations.

When asked to rank people in terms of their degree of vulnerability, the sample managed to identify a person with a disability (PWD) as being the most vulnerable. Analysis of the current legislation shows that disability issues have not deliberately been addressed. Even the draft National Disaster Risk Management Policy as revised in 2011 does not make any mention of disability. The 18 specific objectives of the Policy document (p. 15) do not have anything on disability. There is some hope, however, where the document talks about the establishment of a National Disaster Risk Management Plan, that according to s. 4.5 (p. 17) of the draft document, facilitates:

- the involvement of the private sector, non-governmental organisations, traditional leaders, technical experts and volunteers in DRM

- community participation in DRM

- partnerships for the purposes of the above between organs of State and the private sector, non-governmental organisations and communities.

The document also goes on to indicate that there will be a 'comprehensive information management system, taking into account indigenous knowledge relating to disaster risk management' (p. 18). This tends to point towards a more inclusive approach that has the potential to draw from the people most affected by disasters.

It is evidence of their trust in the government that $37.6 \%$ of respondents indicated that GoZ should be involved in disaster situations. When people have so much belief and confidence in the capacity of their government to handle disasters, there are then policy implications in terms of devoting resources toward enhancing the capacity of government employees and structures to be able to be involved in disaster issues. This is a far cry from the current scenario where disaster management issues are being spearheaded by NGOs, UN agencies and in some cases even 'specialists', with less room for government and the affected people. In the table on institutional involvement in DRR (Table 4), five out of the top 10 are government-related institutions. These are Agritex, the Ministry of Health and Child Welfare, ZRP, RDCs and EMA. On an effectiveness scale of 1 to 5 , with 1 being excellent to 5 being worst, these institutions collectively got an average rating of 3 out of 5 . Also of note is that of the total 53 institutions mentioned by respondents as being involved in DRR initiatives, only 18 are government-related. According to UNDP (2012: 3), the case of Mozambique, the second most disaster-prone country in Africa, shows how institutional strengthening and capacity-building initiatives have saved lives in the long term. Mozambique has dealt with over 45 natural hazards since 1976, including devastating floods, droughts and cyclones. UNDP supports the government at the policy, programming, and operational level to develop DRM strategies, risk mapping and early warning systems. In 2010, with the help of UNDP, the government established a regional emergency operations centre at Caia, in the high-risk Central Region. The centre's training exercises and practice simulations of flood, cyclone and earthquake responses have noticeably improved the emergency preparedness of the region and resulted in a significant reduction of the disaster death toll over the last decade. Between 2001 and 2010, the total number of disaster-affected people in Mozambique was reduced by almost $45 \%$ compared with the previous decade. Floods in 2000 left 800 people dead and over a half a million affected, whilst flooding of a similar magnitude in 2007, after six years of disaster preparedness initiatives, left only 29 people killed and 70000 displaced. Flood-related mortality in 2010 was less than $25 \%$ of the 10 -year average and although 16000 people were affected by flooding in 2010 , this represented a decrease of more than $90 \%$.

Even though these respondents indicated that other actors in the development field should be involved in DRR, they did not seem to think they too could play a role in the same. From a rights-based perspective, even though government has the overall mandate to protect its citizens, individuals should have a role to play, as they are the first responders (albeit unofficially). Closely related to this is the fact that when asked to rate their ability to respond to disasters, a total of $41 \%$ of respondents felt that their ability to respond to disasters ranged from good to excellent. If people can rate 
themselves so well, why would they then relegate their direct involvement in disaster response? We have also seen that when asked to explain their mode of involvement in disaster issues, a total of $65.2 \%$ of respondents said that they were either not sure what to do, that there were barriers to their involvement, or that they had no responsibility with regard to handling disasters. This arguably points to policy factors that have to do with creating an enabling environment wherein DRM ceases to be the sole preserve of specialists, consultants and technocrats, but becomes incorporated into the daily activities of all citizens.

The humanitarian world has of late been promoting human rights-based approaches in their programming. This has good intentions, and if achieved, could go a long way toward redefining the duties, obligations and relationships amongst the various players in humanitarian work. We have noted how a considerable proportion of respondents is composed of people who have gone up to post-secondary education. However, what was striking was their lack of awareness of human rights issues in development and DRM. Some of them are already involved in humanitarian work, especially those undertaking Master of Science degree studies in Disaster Management and Development Studies at NUST. It is probably this lack of awareness of human rights issues on the part of development professionals that is also contributing to the formulation and enactment of 'blind' policies that do not fully incorporate the most vulnerable people, particularly those with some disability. In Zimbabwe, apart from disability organisations, there have only been partial attempts to address disability in humanitarian work through humanitarian protection (including Humanitarian Accountability) and the Sphere Standards in emergencies. However, the key question remains: what about the longerterm developmental approach of DRR?

It could be submitted that DRM policy in Zimbabwe, if widely circulated for consultation in its draft state, could get a lot of input from such a highly literate populace. It would also have achieved an easier buy-in, as the people consulted could easily identify therewith. It would also be much easier to conduct awareness campaigns if they were well packaged for the different audiences in the country. It is also evident that informal education, formal education, television and radio are playing a role in raising awareness on disasters and in early warning awareness campaigns. There could be scope for use of these media in DRM policy awareness campaigns and risk communication. It has been noted that the policy draft document has been circulated largely to people with DRM backgrounds for their input. However, we need to bear in mind that the person most affected by a disaster may not be aware of disaster policy issues but can provide input to make the formulation process more inclusive. An individual may not be aware of disaster jargon and principles, but is, at the same time, directly involved in DRR initiatives on a daily basis, even though they may not regard it as DRR. These kinds of people possess a wealth of insights into and experience in disaster risk issues that could be tapped into.
From the data obtained it is clear that when asked to indicate where they got support during disaster-induced hardships, $27.5 \%$ of respondents indicated that they get support from NGOs, $14.7 \%$ from extended family and $13.8 \%$ from community. If NGOs are the dominant player in times of hardships, then most communities are treading on the undesirable road of dependence. What could happen to these communities if the NGOs suddenly withdrew from their area, or if their funding ran out? This cannot be ruled out, especially considering the austerity measures happening in most European countries, which are amongst the major donors to humanitarian organisations and programmes. Inclusive policies need to cede more power to the people to allow them to assist each other in times of hardship. Disaster policy in Zimbabwe needs to make provision for greater local level mutual support arrangements. There is a need to build on the traditionally-existing extended family system and local community support systems as part of reducing vulnerability and building and strengthening resilience.

\section{Conclusion}

Official channels related to disaster management are dominated by non-affected or suppressive and patriarchal groups. As so often happens in everyday life, the disabled stay behind the scenes during disasters, or are even hidden by families, making it difficult to acknowledge either their concerns or their contributions. When taken to an extreme, this tradition can put the disabled at increased vulnerability to risk and danger. As the World Bank (2006) opines, the challenges before us will be related specifically to measures of integrating uniform engagement of the various groups in the planning segment of disasters, with an understanding of disability as a social and human rights issue; to get governments and civil society activists to plan the research agendas together; and to take into account cross-current issues such as gender environment, psychosocial issues, disability diversity concerns, human and material resources, and training and networking. The legal framework in Zimbabwe, as in other parts of the world, should mandate involvement by vulnerable people and their communities, Red Cross, Red Crescent, civil society and the private sector in risk reduction. Strengthened laws and policies will support the allocation of adequate funding for work with vulnerable people and their communities, risk mapping, access to disaster information, development planning, enforceable building codes and land use planning, and accountability for results (IFRC 2012:16). Evidence suggests that lack of awareness and appreciation of accessibility as a cross-cutting development issue, as well as an absence of appropriate policy guidance on promoting accessibility in the context of development, have been challenging obstacles in the furthering of achievement of the Millennium Development Goals, as well as other internationally-agreed outcomes for all - persons with disabilities in particular. As the United Nations Children's Fund (UNICEF 2006:32) asserts, the human rights-based approach to programming stresses participatory approaches that engage communities in planning, implementation and monitoring processes. This means that we should build on 
what people already know and that we recognise both their social and cultural strengths. However, communities are not homogeneous. We need to keep in mind that vulnerabilities related to age, gender inequalities, ethnicity, caste, socioeconomic status and disability are factors that may affect people's ability to take part in decision-making processes. This needs to be addressed even as Zimbabwe works on amending its DRM policy framework for increased disaster resilience.

\section{Acknowledgments Competing interests}

The authors declare that they have no financial or personal relationship(s) which may have inappropriately influenced them in writing this article.

\section{Authors' contributions}

P.P.B. (Institute of Development Studies, National University of Science and Technology [IDS-NUST]) was the project leader in documentation and development of research instruments, P.T.C. (IDS-NUST) was the team leader of the Disaster Risk Reduction Unit (DRRU) at IDS-NUST, and also responsible for development of research instruments, M.S. (IDS-NUST) and F.M. (IDS-NUST), were responsible for leading fieldwork and brainstorming on key thematic issues.

\section{References}

Albert, B. \& Hurst, R., 2004, 'Disability and a Human Rights Approach to Development', Disability Knowledge and Research briefing paper, viewed 10 July 2012, from http://hpod.org/pdf/human-rights-approach.pdf

Benson, C. \& Clay, E.J., 1998, The Impact of Drought on Sub-Saharan African Economies: A Preliminary Examination, World Bank Technical Paper Series, No. 401, World Bank, Washington, D.C. http://dx.doi.org/10.1596/0-8213-4180-4

Benson, C. \& Clay, E.J., 2001, Dominica: Natural Disasters and Economic Development in a Small Island State, Disaster Risk Management Working Paper Series, No. 2 World Bank, Washington, D.C.

Benson, C. \& Clay, E.J., 2002, Bangladesh: Disasters and Public Finance, Disaster Risk Management Working Paper Series, No. 6, World Bank, Washington, D.C.

Benson, C. \& Clay E.J., 2004, 'Beyond the Damage: Probing the Economic and Financial Consequences of Natural Disasters', Humanitarian Exchange 27, 44-47.

Chikoto, G.L., 2004, Zimbabwe's Emergency Management Systems, Disaster Management Class Project, Georgia State University, Atlanta, Georgia.
Chikoto, G. \& Sadiq, A., 2012, Zimbabwe's Emergency Management System: A Promising Development, Milwaukee, U.S., unpublished research project, Promising 03 evelopment, Milwaukee, U.S., unpublished research project,
viewed 03 August 2012, from http://training.fema.gov/EMIWeb/edu/ viewed 2012,

Ghai, Y., 2001, 'Human rights and social development: toward democratization and social justice', UNRISD Democracy, Governance and Human Rights Programme Paper 5, UNRISD, Geneva, viewed 15 July 2012, from http://www.ucl.ac.uk/dpuprojects/drivers_urb_change/urb_governance/pdf_democ_empower/UNRISD projects/drivers_urb_change/urb_governt.pdf
Ghai_HR_and_Social_Development.pdi

IFRC, 2012, The Road to Resilience: Bridging relief and development for a more sustainable future, IFRC discussion paper on resilience - June 2012, International federation of the Red Cross and Red Crescent Societies, viewed 28 July 2012, from federation of the Red Cross and Red Crescent Societies, viewed 28 July 2012, from http://www.ifrc.org/Page

InterWorks, 1998, Model for a National Disaster Management Structure, Preparedness Plan, and Supporting Legislation, viewed 14 March 2012, from http://www. preventionweb.net/files/5142_US01MH840-Ft.pdf

Kabeer, N., 2002, 'Citizenship, affiliation and exclusion: Perspectives from the South', IDS Bulletin 33(2), 12. http://dx.doi.org/10.1111/j.1759-5436.2002.tb00021.x

Madamombe, E.K., 2004, 'Zimbabwe: Flood Management Practices-Selected Flood Prone Areas Zambezi Basin', unpublished paper, WMO/GWP Associated Programme on Flood Management, viewed 13 March 2012, from http://www. apfm.info/pdf/case_studies/zimbabwe.pdf

Nyamu-Musembi, C., 2005, 'An Actor-Oriented Approach to Rights in Development', IDS Bulletin, 36(1), 41-51. http://dx.doi.org/10.1111/j.1759-5436.2005.tb00177.x

The World Bank, 2006, 'Managing climate risk: Integrating adaptation into World Bank Group operations', viewed 08 July 2009, from http://siteresources.worldbank. org/GLOBALENVIRONMENTFACILITYGEFOPERATIONS/Resources/PublicationsPresentations/GEFAdaptationAug06.pdf

UNDP (United Nations Development Programme), 2000, Human Development Report 2000, Oxford University Press, New York.

UNDP, 2012, Putting Resilience at the Heart of Development: Investing in Prevention and Resilient Recovery, UNDP Representative Office, Japan.

UNICEF (United Nations Children's Fund), 2006, Behaviour change communication in emergencies: A toolkit, United Nations Children's Fund Regional Office for South Asia (UNICEF ROSA), Nepal.

UNISDR, 2005, 'Disaster Risk Reduction Efforts in Zimbabwe', viewed 20 July 2012, from http://www.unisdr.org/2005/mdgs-drr/national-reports/Zimbabwe-report. pdf

United Nations, 1945, 'Charter of the United Nations', viewed 07 June 2012, from http://www.hrweb.org/legal/undocs.htm

United Nations, 1948, 'Universal Declaration of Human Rights', viewed 07 June 2012 from http://www.hrweb.org/legal/undocs.html

United Nations, 1966a, 'Covenant on Economic, Social and Cultural Rights', viewed 07 June 2012, from http://www.hrweb.org/legal/undocs.html

United Nations, 1966b, 'Covenant on Civil and Political Rights', viewed 07 June 2012, from http://www.hrweb.org/legal/undocs.html

United Nations, 1986, 'The Declaration on the Right to Development' viewed 22 July 2012, from http://www.un.org/documents/ga/res/41/a41r128.htm

Zimbabwe, 1989, The Civil Protection Act 5 of 1989, Parliament of Zimbabwe, Harare.

Parliament of Zimbabwe, 2001, Civil Protection Act (Ch. 10:06 [Acts 5/1989, 3/1992, 22/2001 \{s. 4\}]), Parliament of Zimbabwe, Harare.

Zimbabwe, 2011, National Disaster Risk Management Policy, (Draft) (Number 1, revised 19th August 2011) (unpublished, for consultative purposes only), Government of Zimbabwe, Harare. 